\title{
Addressing Poverty in Ghana: The Role of Home Economics Education
}

\author{
Arkhurst, A. E. (PhD) \\ Department of Home Economics, University of Education, Winneba, Ghana
}

\begin{abstract}
This paper focused on the role Home Economics education can play in poverty alleviation. It identifies poor education as a serious major contributing factor to poverty. It highlights the problems of poverty and concludes by suggesting measures for coping with the problems and alleviating poverty in Ghana.
\end{abstract}

\section{Introduction}

Poverty is a problem of the whole world, both developed and developing nations. The International Fund for Agricultural Development (1992) supports this by saying that "disparity of income and life has been a fact of humanity since the beginning of society; the poor have always out numbered the rich." According to the Ghana Poverty Reduction Strategy (GPRS) 2002 - 2004, over the past ten years, Ghana has experienced growing and deepening poverty an evidence of intensification of vulnerability and exclusion among some areas, especially in the north of the country and the central region. Five out of ten regions in Ghana had more than $40 \%$ of their population living in poverty in 1999. The GPRS (2002) continued that the worst affected areas being the three northern savannah regions (the Upper East, Upper West and Northern Regions). Nine out of ten people in the Upper East, eight out of ten in Upper West, seven out of ten in Northern Region and five out of ten in Central and Eastern Regions were classified as poor in 1999. Ghana's economy, since the early 1990s, has been characterised by high rates of inflation, high interest rates, continuous depreciation of the cedi, dwindling foreign reserves, excessive public debt and stagnant economic growth (GPRS, 2002). As a result, both growth and incomes have remained stagnant. This stagnation in growth of the economy in the 1990s has produced less than acceptable levels of poverty reduction.

Poverty is endemic in Ghana and its impact can be seen all over the country. A number of poverty indicators, characterised by low income, low economic growth, low productivity, ineffective educational system, unemployment, worker-retrenchment, violence, crime and corruption are prevalent. If these characteristics are not properly addressed, indications are that they will persist. Measures so far taken by the government on poverty alleviation have not yielded the desired results. Some of these measures included Operation Feed Yourself (OFY); Economic Recovery Programme (ERP); Structural Adjustment Programme (SAP); Programme of Action to Mitigate the Social Cost of Adjustment (PAMSCAD). Eventually Ghana had to join the Highly Indebted Poor Countries (HIPC) initiative to reduce foreign debts. Some individuals have even accepted the fact that there is nothing they can do to come out of their wretched situation and have given up. Life does not have to be that bad. Enyi and Akpan (2002) expressed similar views about the situation in Nigeria which happens to be a former British colony like Ghana. 


\section{The Concept of Poverty}

Poverty is the lack of the means to satisfy the basic necessities of life. The World Bank (1997) explains that poor people live without fundamental freedoms of action and choice that the better-off of in society take for granted. They often lack adequate food and shelter, education and health, deprivations that keep them from leading valued life. They are often exposed to ill treatment by society and individuals and are powerless to influence key decisions affecting their lives. Poverty is pronounced deprivation in well-being. To be poor is to be hungry, to lack shelter and clothing, to be sick and not cared for, to be illiterate and not schooled (World Bank, 1997). Poor people are particularly vulnerable to adverse events outside their control. They are often treated badly by institutions of state, society and excluded from voice and power in these institutions. This is confirmed by Abdullahi (1996) when discussing poverty alleviation in Ghana, Uganda, Zambia and Malawi.

\section{Causes of poverty}

The causes of poverty are complex and interrelated. The World Bank's Africa Region Poverty Task Force concluded that the basic causes of poverty are lack of access to services and opportunities and inadequate endowments specifically:

- inadequate access to employment opportunities,

- inadequate access to the means of supporting rural development in poor regions,

- inadequate access to markets for goods and services that the poor can sell, low endowment of human capital as a result of inadequate access to education, destruction of natural resource endowments,

- inadequate access to assistance for those living at the margin and those victimised by transitory poverty,

- inadequate participation of the poor in design of development programmes.

The large number of people in poverty implies an inefficient use of resources and increases the risks of social upheaval. Large population makes the situation more complex. Poor education and large illiterate population is a serious major contributing factor to poverty.

\section{Home Economics Education and Career Opportunities}

The definition of Home Economics adopted by the Ghana Home Economics Association in Axim was "an applied science concerned with the development and effective use of human and material resources and community for a better quality of life" (Nsarkoh, 1976). Fleck (1980) posits that the focus of Home Economics is the family in its various forms. Home Economics is a field of knowledge and services primarily concerned with strengthening the family life through educating the individuals and families and the means to satisfying these needs. Olaitan and Agusiobo (1981) also defined Home Economics as the study of all the elements of family living and everything that involves or relates to the welfare of the family members. It is a field of study that provides the necessary knowledge for guiding human beings towards a more self-rewarding and fulfilled life, within the context of home management and family life. The American Home Economic Association says Home Economics is a "field of knowledge and service concerned primarily with strengthening family life (East, 1980).

From the above definitions, one can conclude that home economics education should be the blue print for life and that every human being must have home economics education to go through life confidently. Anyakoha (2001) confirms this idea by saying that home economics helps with the development, use and management of human and material, resources, for the greater welfare of individuals, families and human society in its entirety. It 
strives to solve the most pressing problems that challenge the families now as well as emerging ones. These problems include poverty. Global unemployment and constant retrenchment in Ghana has made it clear to every Ghanaian to strive for a more reliable and independent mode of survival. This can be achieved if one is basically equipped with the relevant knowledge and practical skills. Home Economics is a skill oriented subject which is capable of equipping the graduates with knowledge and skills which will enable them be self-employed and contribute effectively to the socio economic development of the individual, the family and the society (Uzoezie, 1990).

In Ghana, the objectives of the home economics programme for senior secondary schools, according to the syllabus, are to:

1. equip the individual to develop skills that will enable him/her improve the quality of life.

2. understand the factors in the family, community and society which help in meeting basic needs

3. recognise the importance of good consumer skills in all areas of life.

4. apply management skills in all aspects of living.

5. appreciate the need for healthy living through improved sanitation and environment.

6. develop skills that will equip students for independent living.

7. to acquire knowledge and develop marketable skills which can be used in later life (Ministry of Education, 1986:iii).

Home economics aims at providing marketable skills. This is in line with the general aims of the new education reforms. Home economics education should be able to contribute to manpower development by equipping individuals with occupational skills to make them self-reliant. This is confirmed by Anyakoha (1988) who noted that Home economics occupations abound and that Home Economics is capable of preparing youths and adults for entry into various Home Economics occupations. Some of the career opportunities in Home Economics include: teaching, home economists in businesses such as catering, sewing, interior decorating, dietetics, research, child caring, running a laundry, etc.

Apart from the above listed careers, Home Economics education helps the individual to improve the quality of his/her life which improves self worth or self esteem. The programme helps one to understand factors in the family, community and society which help in meeting basic needs. It makes people more responsible and provides good consumer skills in all areas of life. It empowers consumers to be more assertive in the market place so that they get their money's worth. They buy good quality goods which will last longer. They do not buy on impulse and thus save money. They plan and budget to live within their income and thereby stretch their income.

Home Economics education also provides management skills in living and help people to appreciate the need for healthy living through improved sanitation and environment. When the family is healthy, they can work harder. At the same time they do not spend money on medical bills. The course teaches knowledge in planning and preparing healthy nutritious meals which help develop the brain and maintain healthy bodies. The benefits of Home Economics education cannot be over emphasized in the eradication of poverty both in the family and in the nation.

Some ways in which home economics education can help provide employment to reduce poverty are:

i. Caterer - operate a restaurant or cater for functions, operate a bakery.

ii. Sewing - establish a sewing school to train others and open a boutique to sell garments and sew custom made garments. 


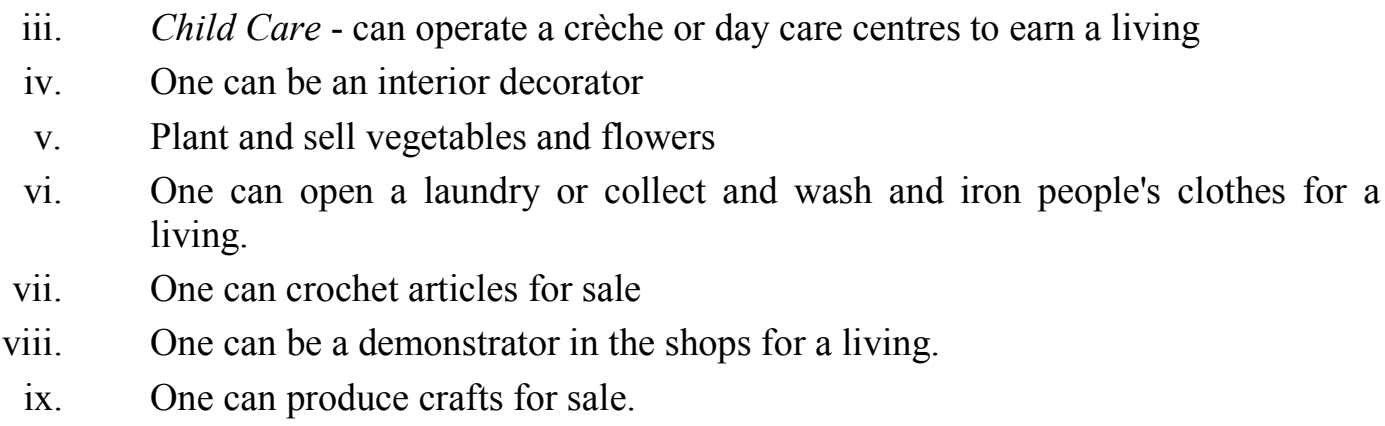

\section{Summary and Recommendations}

Home Economics is a skill oriented subject that equips individual with marketable skills. It also equips students with consumer and management skill. All these help to make individuals save money, become self employed and manage better the available resources as well as prevent diseases and poverty. Based on the discussion above, the following recommendations are made:

1. Government should involve Home Economists in the planning and implementation of any poverty alleviation programme.

2. Home Economists should use their professional skills to teach women folks especially the unemployed

3. Home Economists extension workers should evolve special poverty alleviation initiatives for women groups based on their environmental needs.

4. Home Economists should counsel families and organise talks to help the rural poor improve their resource management skills and their lives.

5. The home economic association should come out more to adopt some villages and help the women folk and children.

6. Home Economics education is very vital for living so all students should be made to study Home Economics to senior secondary level to prepare them for life.

\section{References}

Abdullahi, M.Y. (1996) Poverty and Approaches to Poverty Alleviation in Ghana, Uganda, Zambia and Malawi in B. Michad, C, M.Y. Abdullahi and G. Matovu (eds) The Design and Management of Poverty Reduction programmes and projects Anglophone Africa. (Proceedings of a seminar sponsored jointly by the Economic Development Institute of the World Bank and the Uganda Management Institute. Washington D.C. The World Bank.

Anyakoha E.U. (1988) Strategies for effective Development and Utilization of Facilities for Implementation of Home Economics Education Programme in schools and colleges. A paper presented at the National Home Economics Workshop for Home Economists in the Post-Secondary Institutions, University of Ibadan, Nov. 810.

Anyakoha, E.U., (2001). Welcome address presented at the opening ceremony of the second National Conference of Home Economics Research Association of Nigeria held in University of Nigeria, Nsukka $5^{\text {th }}-8^{\text {th }}$ Sept. 2001.

East, M. (1980). Home Economics: Past Present and Future. Boston: Allyn and Bacon INC 
Enyi, D. and Akpan, G.O. (2002) Addressing Poverty in Nigeria: The Role of Education. Journal of Nigerian Educational Research Association., Vol.14 No. 1.

Flecks, H. (1980) Towards Better Teaching of Home Economics New York: Macmillan Publishing Co. INC.

GPRS - Ghana Poverty Reduction Strategy Republic of Ghana (2002). Eleventh Consultative Group Meeting (Volume Two) Ghana Poverty Reduction Strategy (2002-2004) April 8-10 p.iii-vii.

Ministry of Education (1986) Home Economics Syllabus for Senior Secondary School Accra: Wisdom Press Ltd.

Nsarkoh, J. (1976). The Value of Home Science Education: The Home Scientist. Journal of the Ghana Home Science Association Vol. 4 No. 3-4. pp9-15.

Olaitan, S.O. and Agusioba, N.O. (1981) Introduction to the Teaching of Home Economics. New York: John Wiley and Sons Inc.

Uzoezie, C.E. (1990) Infrastructural Facilities for Effective Teaching and Learning of Home Economics - An Appraisal. ANVIL, Journal of Educational Studies 2 (2) 1-15.

World Bank (1997) Development in Practice. Taking Action to Reduce poverty in Su-Sahara Africa. Washington DC: The World Bank 